\title{
Infection of the lesser spotted dogfish with Proleptus obtusus Dujardin, 1845 (Nematoda: Spirurida) reflects ontogenetic feeding behaviour and seasonal differences in prey availability
}

\author{
Carlota Silva ${ }^{1}$, Ana Veríssimo ${ }^{1,2}$, Pedro Cardoso ${ }^{1}$, Jo Cable $^{3}$ and Raquel Xavier ${ }^{1 *}$ \\ ${ }^{1}$ CIBIO, Centro de Investigação em Biodiversidade e Recursos Genéticos, Campus Agrário de Vairão, Rua Padre Armando Quintas, \\ 4485-261 Vairão, Portugal; ${ }^{2}$ VIMS, Virginia Institute of Marine Science, College of William and Mary, Route 1208, Greate Road, \\ Gloucester Point, VA 23062, USA; ${ }^{3}$ School of Biosciences, Cardiff University, Cardiff, CF10 3AX, UK
}

\begin{abstract}
Proleptus obtusus Dujardin, 1845 is the most common parasite infecting the gut of the lesser spotted dogfish (Scyliorhinus canicula, Linnaeus). This nematode is trophically transmitted from an intermediate crustacean host to the definitive elasmobranch host. Sexual and age-related differences in habitat occupancy and feeding behaviour of the lesser spotted dogfish make this parasite-host dyad ideal for testing which aspects of host biology influence parasite transmission. Here, the relationship between P. obtusus burden and host condition, sex and age were investigated in lesser spotted dogfish captured in the Northeast Atlantic. Prevalence of $P$. obtusus was of $94.8 \%$ with a mean abundance of 23.3 worms per host. Our results indicate that parasite burden is best explained by the interaction between ontogenetic differences in foraging behaviour of the lesser spotted dogfish and seasonal differences in prey availability.
\end{abstract}

\section{Keywords}

Scyliorhinus canicula, parasite trophic transmission, ontogenic feeding behaviour

\section{Introduction}

Nematodes are one of the most common pathogens infecting sharks (Garner, 2013). Proleptus Dujardin, 1845 (Spirurina: Physalopteridae) is one such nematode genus, with species commonly parasitising the gut of elasmobranchs (Moravec et al., 2002). Proleptus spp. rely on predator-prey interactions to complete their life cycle, with early larval stages infecting decapod crustaceans as obligate intermediate hosts but sexual maturity is only attained in the definitive elasmobranch host (Moravec 2007). Clinical signs of infections with Proleptus sp. are usually mild and restricted to local inflammation of the stomach wall, although repeated attachment of the nematodes can seriously wound the host (Heupel and Bennett, 1998a).
To the best of our knowledge, six parasitological studies have been conducted on the lesser spotted dogfish, Scyliorhinus canicula (Linnaeus), and only three parasitic nematodes were reported, all infecting the digestive tract: adult Proleptus obtusus Dujardin, 1845, and third stage larvae of both Anisakis simplex (Rudolphi, 1809) and Pseudoterranova decipiens (Krabbe, 1878) (see Table I for a summary). P. obtusus was the only species reported in all studies and was by far the most common, with $67-100 \%$ prevalence and up to 177 parasites per host (Lloret et al., 2012). The reported prevalence of A. simplex is low and P. decipiens is considered to be rare, so far only found in lesser spotted dogfish from Wales and southern England (see Table I). To date, only one study has tested the relationship between infection intensity and host condition (Lloret 
Table I. Summary from the literature of nematode parasites recorded in the digestive tract of the lesser spotted dogfish

\begin{tabular}{|c|c|c|c|}
\hline Locality & Number of hosts & $\begin{array}{c}\text { Nematode parasites species } \\
\text { (Prevalence \%) }\end{array}$ & Reference \\
\hline Plymouth, UK (NE Atlantic) & 37 & $\begin{array}{c}\text { Proleptus obtusus (100) } \\
\text { Anisakis simplex }(10.8) \\
\text { Pseudoterranova decipiens }(5.4)\end{array}$ & Moore 2001 \\
\hline Cardigan Bay, UK (NE Atlantic) & 49 & $\begin{array}{c}\text { Proleptus obtusus (100) } \\
\text { Anisakis simplex (2) } \\
\text { Pseudoterranova decipiens }(53.1)\end{array}$ & Moore 2001 \\
\hline Eastern Solent, UK (NE Atlantic) & 15 & $\begin{array}{l}\text { Proleptus obtusus (100) } \\
\text { Anisakis simplex (13.3) }\end{array}$ & Moore 2001 \\
\hline Western coast of Portugal (NE Atlantic) & 3 & Proleptus obtusus $(66,6)$ & de Oliveira Rodrigues et al. 1973 \\
\hline SW coast of Ireland (NE Atlantic) & 28 & Proleptus obtusus (100) & Casadevall et al. 2010 \\
\hline Blanes, Spain (NW Mediterranean) & 130 & $\begin{array}{c}\text { Proleptus obtusus (96.9) } \\
\text { Anisakidae larvae (0.8) }\end{array}$ & Casadevall et al. 2010 \\
\hline NW Mediterranean & 128 & Proleptus obtusus (97.7) & Lloret et al. 2012 \\
\hline NW Spain (NE Atlantic) & 57 & $\begin{array}{l}\text { Proleptus obtusus (91.2) } \\
\text { Anisakis simplex (3.5) }\end{array}$ & Sanmartin-Duran et al. 1989 \\
\hline Galway bay, UK (NE Atlantic) & 144 & $\begin{array}{l}\text { Proleptus obtusus }(88.2) \\
\text { Anisakis simplex }(4.2)\end{array}$ & Henderson and Dunne 1998 \\
\hline Póvoa do Varzim, Portugal (NE Atlantic) & 58 & $\begin{array}{l}\text { Proleptus obtusus }(94.8) \\
\text { Anisakis simplex }(1.7)\end{array}$ & Present study \\
\hline
\end{tabular}

et al. 2012). In that study, involving 128 individuals caught in the northwestern Mediterranean, no relationship was found between host condition, length and parasite intensity. Instead, the authors suggested that parasite intensity was related to feeding frequency and availability of infected prey (intermediate host).

The lesser spotted dogfish occurs throughout the eastern North Atlantic, from Senegal up to Norway, and in the Mediterranean Sea. The species is very popular for human consumption in the Mediterranean Sea (Capapé et al. 2008), and it is a common fisheries by-catch in the eastern North Atlantic being the main shark species captured in northern Spain and northern France (Cavanagh 2005). Although populations have generally either remained stable or even increased over the last few decades (Jukic-Peladic et al. 2001; UNEP-MAP-RAC/SPA 2013; Coll et al. 2014; McHugh et al. 2011), declines in lesser spotted dogfish landings have been reported for the Aegean Sea (Damalas and Vasilopolou, 2011), the Adriatic Sea (Barrausse et al., 2014) and the Tyrrhenian Sea (Ferretti et al. 2005).

The lesser spotted dogfish is considered a generalist predator feeding mostly on crustaceans and pelagic bony fishes, but there are recognized ontogenetic differences in feeding behaviour with adults consuming more teleosts than juveniles (Olaso et al. 2005; Valls et al. 2008; Martinho et al. 2012; Šantić et al. 2012). Martinho et al. (2012) also hypothezised that there could be habitat segregation between juveniles and adults during winter off Portugal, based on their different diets at this time of year, in sharp contrast to the other seasons. Other ontogenetic differences have been reported for this species, with juveniles occurring in shallower waters than adults in the
Cantabrian Sea (Olaso et al. 2005). Sex-related differences in feeding patterns were also observed, with adult females feeding less during spring and summer, in contrast to adult males and juveniles of both sexes that increase their feeding rate during these seasons thus matching the higher abundance of prey (Martinho et al. 2012). A high degree of spatial segregation with depth has been described for this species, with males and females in southwest Ireland occupying different depth-related habitats (Sims et al. 2001). Importantly, there is a known effect of depth in the diet of the species: individuals captured on the continental shelf feed on reptantians, polichaetes and teleosts, whereas individuals from deeper habitats feed mostly euphausiids (Valls et al. 2008).

The present study aimed to assess the gastro-intestinal helminths of lesser spotted dogfish captured in Northern Portugal. Specifically, we hypothesized that sex and ontogenicrelated differences in feeding behaviour and habitat use influence parasite burden (e.g. Sims et al. 2001; Martinho et al. 2012). We also expected to find seasonal differences in parasite abundance since host feeding activity is reportedly higher in spring and summer due to the higher availability of prey, except in the case of adult females which are expected to decrease feeding activity during this period (Martinho et al. 2012).

\section{Materials and Methods}

A total of 58 lesser spotted dogfish caught by coastal artisanal fisheries were purchased from a fish auction on five separate 
occasions between November 2013 and March 2014 at Póvoa do Varzim (Northern Portugal, see Table II for details). Total length (from tip of the snout to tip of caudal fin, TL) and total weight (TW) were recorded to the nearest millimeter and gram, respectively. Sex of each shark was determined visually by presence/absence of claspers, and maturity stage was determined using the criteria of ICES (2013). Upon dissection, weight of liver and gonads (testes and ovaries) was recorded. Hepatosomatic (HSI) and gonadosomatic indices (GSI) were calculated using the following formulas: HSI = $(\mathrm{LW} / \mathrm{TW}) \times 100$ and GSI $=(\mathrm{GW} / \mathrm{TW}) \times 100$. These two indices were used as proxies for overall body condition (e.g. Lambert and Dutil 1997). Stomach and gut contents were emptied into petri dishes and the contents carefully searched for any helminths, which were recovered and stored in $96 \%$ ethanol. Parasites were observed under a light microscope (Olympus CX4). Proleptus obtusus were identified based on the presence of a cephalic collar and the conical shape of the caudal region (Moravec et al. 2002). Furthermore, in females, the placement of the vulva was located on the posterior tip of the animal, very close to the anal opening (Moravec et al. 2002). Anisakis simplex were identified following the diagnosis of Hurst (1984). To validate morphological identification, we sequenced a portion of the $18 \mathrm{~S}$ rRNA gene of 22 randomly selected $P$. obtusus collected from 5 different hosts (two adult females collected in winter and spring, two adult males collected in winter and one pre-adult female collected in the autumn), for direct comparison with a Proleptus sp. sequence available on GenBank (Accession Number JF934733). The hotSHOT DNA extraction protocol was used (MonteroPau et al., 2008) as well as the polymerase chain reaction (PCR) procedure of Perera et al. (2013). Finally, since the taxonomy of Proleptus is controversial because of high intraspecific morphological plasticity (Moravec et al. 2002, 2007), and to assess levels of genetic variability, a portion of the $28 \mathrm{~S}$ rRNA was sequenced from the same individuals. PCR primers were the 28S rD1.2a and 28Sb of Whiting (2002), and the PCR protocol was as follows: preliminary denaturation for $3 \mathrm{~min}$ at $94^{\circ} \mathrm{C}$, followed by 35 cycles of $30 \mathrm{~s}$ at $94^{\circ} \mathrm{C}, 30 \mathrm{~s}$ at $55^{\circ} \mathrm{C}$ and $1 \mathrm{~min}$ at $72^{\circ} \mathrm{C}$; and a final extension at $72^{\circ} \mathrm{C}$ for 10 min. Since the 28S rRNA sequences showed no variation (see Results and Discussion of details), we also sequenced the mitochondrial "barcoding" cytochrome oxidase subunit 1 (COI) gene for 15 of the individuals initially analysed for the $18 \mathrm{~S}$ and $28 \mathrm{~S}$ rRNA, plus another 39 individuals randomly selected from the remaining hosts. For COI amplification, the primers and PCR conditions were used according to Prosser et al. (2013). Unique haplotypes for 18S rRNA, 28S rRNA and COI were deposited in GenBank (Accession Numbers: KY411561KY411576).

A generalized linear model (GLM) was used to test the effects of TW, TL, GSI, HSI, host sex, season and maturity stage on parasite abundance. Collinearity between variables was inspected using pairwise correlation coefficients and variance inflation factors (VIF). VIF values were obtained using

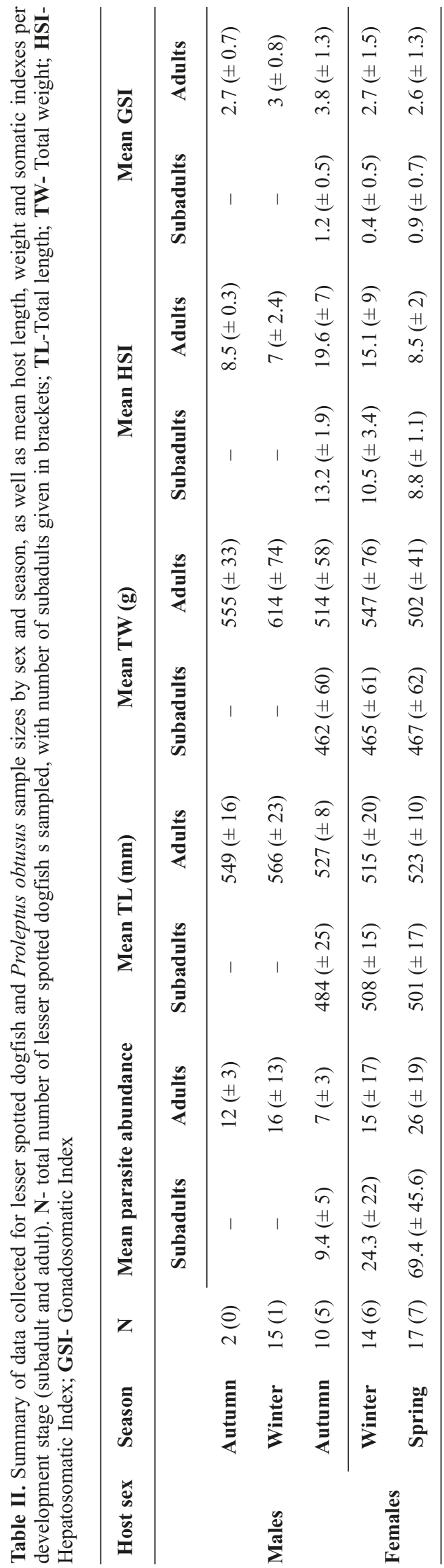


the 'vif' function implemented in R package 'car' (Fox et al. 2012). A Poisson regression was fitted to the data and since overdispersion was detected (overdispersion parameter $>1$ ) standard errors were corrected using a Quasi-Poisson model (Zuur et al. 2009). To find the optimal model the drop1 command was used (Zuur et al. 2009).

\section{Results}

Table II summarizes morphological and parasitological data collected on lesser spotted dogfish from Northern Portugal. Nematodes were found in $94.8 \%$ of sharks $(n=58)$, most in the stomach rather than in the intestine. Proleptus obtusus numbers ranged from 1 to 169 , with a mean abundance of 23.3. Additionally, two individuals of Anisakis simplex were found co-infecting a single host. Host total length (TL) was highly correlated with sex and total weight (TW) (correlation coefficients of 0.7 and 0.8 , respectively). Likewise, the gonadossomatic index (GSI) was highly correlated with maturity stage (correlation coefficient of -0.7$)$. All other variables had moderate correlation coefficients $(\leq \pm 0.6)$. For this reason both GSI and TL were not included in the analysis. For the remaining variables, the VIF values were below 3 and as such

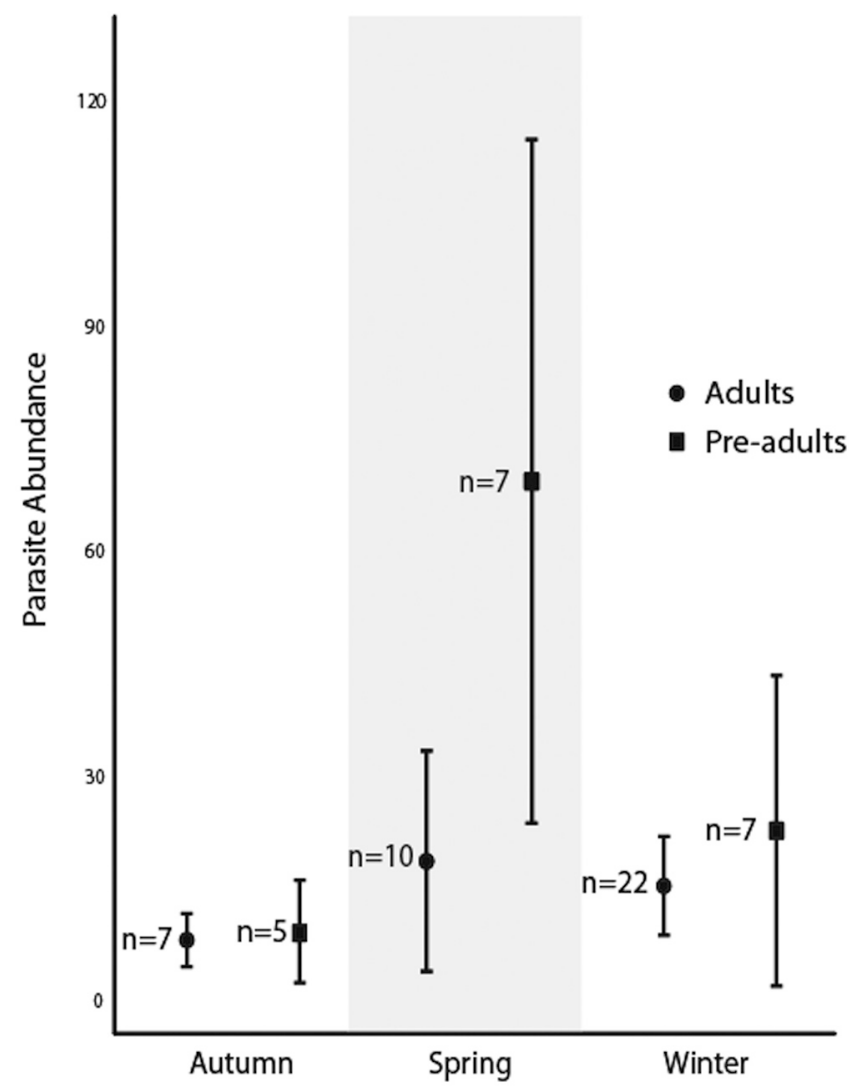

Fig. 1. Seasonal variation in the mean abundance (and corresponding 95\% confidence interval) of Proleptus obtusus infecting preadult and adult lesser spotted dogfish Numbers of individuals included in each class are also depicted there was no reason to exclude them a priori (Zuur et al. 2009). The drop1 command sequentially excluded variables HSI $(p=0.428)$, sex $(p=0.139)$ and TW $(p=0.07)$. For this reason, the final model retained only the effects of season and maturity stage. Post-hoc comparisons of season $\times$ maturity stage groups revealed a significantly higher abundance of parasites in pre-adults in spring $(\mathrm{p}<0.05$, Fig. 1).

Some individuals of P. obtusus (61 from a total of 1278) were sequenced for at least one gene. The $18 \mathrm{~S}$ rRNA sequences (837 bp) were identical to each other, and had $99 \%$ identity match with the only Proleptus sp. sequence available on GenBank (with 100\% query coverage and differing by only 3 point mutations). Likewise, sequences from the $28 \mathrm{~S}$ rRNA (1060 bp) showed no variation. In contrast, 14 different haplotypes were identified in $54 \mathrm{COI}$ sequences (428 bp), with a total of 14 parsimony informative sites. Uncorrected p-distances between COI sequences varied between $0-3.5 \%$, which is within the range of intraspecific variation reported for several parasitic nematodes $(0-4.3 \%$, see $\mathrm{Hu}$ and Gasser, 2006 for a review).

\section{Discussion}

In line with previous parasitological studies on the lesser spotted dogfish, the prevalence of P. obtusus was high $(94.8 \%)$ and that of $A$. simplex was low (1.7\%) in the current study. Usually, in vertebrates, larger hosts tend to harbour more parasites (e.g. Lo et al. 1998; Poulin and George-Nascimento 2007), and the higher parasite abundance in larger (likely older) hosts could result from increased feeding rates (i.e. larger sharks eat more intermediate and presumed paratenic hosts) and/or parasite accumulation over the host's lifetime (e.g. Heupel and Bennett 1998a). In previous studies, the abundance of Proleptus worms has been positively correlated with host size, as in the case of Proleptus australis Bayliss, 1933 infecting the epaulette shark, Hemiscyllium ocellatum (Bonaterre) (see Heupel and Bennett, 1998a), Proleptus acutus Dujardin, 1845 infecting the Chilean catshark, Schroederichthys chilensis (Guichenot) (see George-Nascimento and Vergara, 1982), and P. obtusus infecting the dark shyshark, Haploblepharus pictus (Muller and Henle) (see Yeld, 2009). However, no such correlation was found for P. obtusus infecting Haploblepharus edwardsii (Schinz) and Poroderma africanum (Gmelin) captured off South Africa (Yeld, 2009), or the lesser spotted dogfish in the Mediterranean region (Lloret et al., 2012). These disparities in results could be indicative that Proleptus burden is highly correlated to the feeding frequency on infected intermediate hosts, i.e. decapods (e.g. George-Nascimento et al. 1994). In fact, in the cases of the epaulette shark, the Chilean catshark and the dark shyshark, there is a recognized increase in the preference to feed on decapods with age (Dainty 2002; George-Nascimento and Vergara 1982; Heupel and Bennet 1998b), which supports the fact that larger sharks of these 
species are more heavily parasitized with Proleptus sp.. $P$. africanum seems to be an exception, as although dietary information indicates an increase in the consumption of decapods with age (Dainty 2002), Yeld (2009) showed that this preference is not always translated in higher parasitic burden in older/bigger sharks. On the other hand, South African populations of $H$. edwarsiii seem to prefer decapods throughout their entire life (Dainty, 2002), which is concordant with the fact that in these populations no relationship between host size and abundance of Proleptus obtusus was detected (Yeld, 2009).

The results from the current study showed that smaller/subadult sharks were more heavily infected than larger adults (see Figure 1), hence supporting our initial hypothesis that ontogenetic differences in foraging behaviour could translate in different parasite abundances. Crustaceans are the intermediate hosts of Proleptus (see Moravec, 2007) and the main prey of lesser spotted dogfish (Olaso et al. 2005; Valls et al. 2008; Martinho et al. 2012; Šantić et al. 2012). However, adult sharks consume a higher proportion of teleosts than juveniles (Olaso et al. 2005; Valls et al. 2008; Martinho et al. 2012; Šantić et al. 2012), and thus could be less prone to infection. Additionally, the impact of depth segregation with ontogeny on the feeding strategy of this shark, and thus on parasite abundance, cannot be discarded (Olaso et al. 2005; Valls et al. 2008).

Habitat use and behavioural segregation between sexes occurs in lesser spotted dogfish with males resting during the day in deep waters and feeding during the night in shallow areas, whereas females rest during the day in shallow waters and feed at night in deeper habitats (Sims et al. 2001). Additionally, adult males and juveniles of both sexes are reported to feed more during spring and summer due to higher prey availability whereas mature female sharks decrease feeding activity during this period (Martinho et al. 2012). In contrast to what we expected, host sex did not affect parasite abundance, indicating that both males and females are feeding with the same intensity on intermediate hosts of P. obtusus despite potential differences in habitat use. Likewise, no significant effects on parasite burden were associated with adult female hosts. However, juveniles did show higher parasite abundances during spring, which is probably a consequence of a higher feeding activity perhaps triggered by higher abundance of prey (including intermediate hosts) in spring (Martinho et al. 2012). Finally, in the present study there was no effect of host somatic indices on parasite abundance, which indicates that host condition does not affect infection ability of parasites.

Overall, our data confirms some of the previous observations made by Lloret et al. (2012) on Mediterranean lesser spotted dogfish, as no relationship was found between the abundance of $P$. obtusus and host sex or somatic indexes, which serve as a proxy for host condition. Our findings suggest that parasite load is best explained by the interaction between age-related foraging behaviour and seasonal differences in prey availability.
Acknowledgements. The authors would like to thank Dr Antigoni Kaliontzopoulou for all the help regarding the statistical analysis. The authors would also like to thank two anonymous reviewers for all the comments which helped improve this manuscript. This work was partially funded by the European Regional Development Fund (ERDF) through COMPETE program and by National Funds through FCT Foundation for Science and Technology (projects EXPL/MARBIO/1034/2012, PTDC/MAR-BIO/4458/2012 and FCOMP-01-0124FEDER- 029939); and partially funded by Norte Portugal Regional Operational Programme (NORTE 2020), under the PORTUGAL 2020 Partnership Agreement, through ERDF under project MarInfo (NORTE-01- 0145-FEDER- 000031). RX and AV are supported by FCT under the Programa Operacional Potencial Humano - Quadro de Referência Estratégico Nacional funds from the European Social Fund and Portuguese Ministério da Educação e Ciência (RX. IF-FCT contract IF/00359/2015; AV post-doctoral grant SFRH/BPD/77487/ 2011).

\section{References}

Barrouse A., Correale V., Curkovic A., Finotto L., Riginella E., Visentim E, Mazzoldi C. 2014. The role of fisheries and the environment in driving the decline of elasmobranchs in the northern Adriatic Sea. ICES Journal of Marine Science. DOI: 10.1093/icesjms/fst222

Capapé C., Reynaud C., Vergne Y., Quignard J.-P. 2008. Biological observations on the smallspotted catshark Scyliorhinus canicula (Chondrichthyes: Scyliorhinidae) off the Languedocian coast (southern France, northern Mediterranean). Pan-American Journal of Aquatic Sciences, 3, 282-289

Casadevall M., Martinez N., King P. 2010. The lesser-spotted dogfish (Scyliorhinus canicula): parasites and scavenger habits. Rapport Commission international Mer Méditerranée, 39, 470

Cavanagh R.D. 2005. Regional Overviews. Sharks, Rays and Chimaeras: The Status of the Chondrichthyan Fishes. IUCN/SSC Shark Specialist Group. Gland, Switzerland and Cambridge, UK, pp. 461

Coll M., Carreras M., Ciércoles C., Cornax M.-J., Gorelli G., Morote E., Sáez, R. 2014. Assessing fishing and marine biodiversity changes using fishers' perceptions: the Spanish Mediterranean and Gulf of Cadiz case study, PLOS ONE 9, e85670. DOI:10.1371/journal.pone.0085670

de Oliveira Rodrigues H., Varela M.C., Sodré Rodrigues S., Cristófaro R. 1973. Alguns nematódeos de peixes do Ocean Atlântico- costa continental Portuguesa e costa do Norte da África. Memória do Instituto Oswaldo Cruz, 71, 247-256

Dainty A.M. 2002. Biology and ecology of four catshark species in the southwestern Cape, South Africa. MSc thesis. University of Cape Town, pp.109

Damalas D., Vassilopoulou V. 2011. Chondrichthyan by-catch and discards in the demersal trawl fishery of the central Aegean Sea (Eastern Mediterranean). Fisheries Research, 108, 142152. DOI:10.1016/j.fishres.2010.12.012

Ferretti F., Myers R.A., Sartor P., Serena F. 2005. Long Term Dynamics of the Chondrichthyan Fish Community in the Upper Tyrrhenian Sea. ICES CM Documents, 25, 1-34

Fox J., Weisberg S., Bates D., Fox M.J. 2012. Package "car". http: //cran.r-project.org/web/packages/car/car.pdf

Garner M.M. 2013. A retrospective study of disease in elasmobranchs. Veterinary Pathology, 50, 377-389. DOI: 10.1177/ 0300985813482147

George-Nascimento M.F., Vergara L.R. 1982. Relationships between some inherent host factors and the size of infrapopulations of Proleptus acutus Dujardin, 1845 (Nematoda: Spirurida) within the stomach of its definitive host, Schroede richthys 
chílensís (Guichenot, 1848) (Chondrichthyes: Scyliorhinidae). Journal of Parasitology, 68, 1170-1172

George-Nascimento M.F., Carmona.R, Renzo R. 1994. Occurrence of larval nematodes Proleptus sp. (Spirurida: Physalopteridae) and Anisakis sp. (Ascaridida: Anisakidae ) in the crab Cancer plebejus Poeppig, in Chile. Scientia Marina, 58, 355-358

Henderson A.C., Dunne J.J. 1998. The metazoan parasites of the lesser-spotted dogfish Scyliorhinus canicula (L.) from the Galway Bay area. The Irish Naturalists'Journal, 26, 104-107

Heupel M.R., Bennett M.B. 1998a. Infection of the epaulette shark, Hemiscyllium ocellatum (Bonnaterre), by the nematode parasite Proleptus australis Bayliss (Spirurida: Physalopteridae). Journal of Fish Diseases, 21, 407-413. DOI: 10.1046/j.13652761.1998.00121.x

Heupel M.R., Bennett M.B. 1998b. Observations on the diet and feeding habits of the epaulette shark, Hemiscyllium ocellatum (Bonnaterre), on Heron Island Reef, Great Barrier Reef, Australia. Marine and Freshwater Research, 49, 753-756

Hu M., Gasser R.B. 2006. Mitochondrial genomes of parasitic nematodes - progress and perspectives. Trends in Parasitology, 22, 78-84. DOI: $10.1016 /$ j.pt.2005.12.003

Hurst R.J.1984. Identification and description of larval Anisakis simplex and Pseudoterranova decipiens (Anisakidae: Nematoda) from New Zealand waters. New Zealand Journal of Marine and Freshwater Research, 18, 177-186. DOI: 10.1080/00288 330.1984 .9516040

ICES. 2013. Report of the workshop on Sexual Maturity Staging of Elasmobranchs (WKMSEL), ICES CM 2012/ACOM:59, 1114 December 2012, Lisbon, Portugal. pp. 66

Jukic-Peladic S., Vrgoc N., Krstulovic-Sifner S., Piccinetti C., Piccinetti-Manfrin G., Ungaro N. 2001. Long-term changes in demersal resources of the Adriatic Sea: comparison between trawl surveys carried out in 1948 and 1998. Fisheries Research, 53, 95-104. DOI: 10.1016/S0165-7836(00)00232-0

Lambert Y., Dutil J-D. 1997. Can simple condition indices be used to monitor and quantify seasonal changes in the energy reserves of cod (Gadus morhua)? Canadian Journal of Fisheries and Aquatic Sciences, 54(S1), 104-112. DOI: 10.1139/f96-149

Lloret J., Faliex E., Shulman G.E., Raga J.-A., Sasal P., Muñoz M., Casadevall M., Ahuir-Baraja A.E., Montero F.E., Repullés-Albelda A., Cardinale M., Rätz H.-J., Vila S. Ferrer D. 2012. Fish health and fisheries, implications for stock assessment and management: the Mediterranean example. Reviews in Fisheries Science, 20, 165-180. DOI: 10.1080/10641262.2012.695817

Lo C.M., Morand S., Galzin R. 1998. Parasite diversity:host age and size relationship in three Coral reef fishes from French Polynesia. International Journal for Parasitology, 28, 1695-1708. DOI: 10.1016/S0020-7519(98)00140-4

Martinho F., Sá C., Falcão J., Cabral H.N., Pardal M.Â.. 2012. Comparative feeding ecology of two elasmobranch species, Squalus blainville and Scyliorhinus canicula, off the coast of Portugal. Fishery Bulletin, 110, 71-84

Mchugh M., Sims D.W., Partridge J.C., Genner M.J. 2011. A century later: Long-term change of an inshore temperate marine fish assemblage. Journal of Sea Research, 65, 187-194

Montero-Pau J., Gómez A., Muñoz J. 2008. Application of an inexpensive and high-throughput genomic DNAextraction method for the molecular ecology of zooplanktonic diapausing eggs. Limnology and Oceanography: Methods, 6, 218-222. DOI: 10.4319/lom.2008.6.218

Received: July 19, 2016

Revised: December 7, 2016

Accepted for publication: December 27, 2016
Moore A.B.M. 2001. Metazoan parasites of the lesser-spotted dogfish Scyliorhinus canicula and their potential as stock discrimination tools. Journal of the Marine Biological Association of the UK, 81, 1009-1013. DOI: 10.1017/S0025315401004982

Moravec F, Van As JG, Dyková I. 2002. Proleptus obtusus Dujardin, 1845 (Nematoda: Physalopteridae) from the puffadder shyshark Haploblepharus edwardsii (Scyliorhinidae) from off South Africa. Systematic Parasitology, 53, 169-173

Moravec F. 2007. Some aspects of the taxonomy and biology of adult spirurine nematodes parasitic in fishes: a review. Folia Parasitologica, 54, 239-257

Olaso I., Velasco F., Sánchez F., Serrano A., Rodríguez-Cabello C., Cendrero O. 2005. Trophic Relations of Lesser-Spotted Catshark (Scyliorhinus canicula) and Blackmouth Catshark (Galeus melastomus) in the Cantabrian Sea. Journal of Northwest Atlantic Fisheries Science, 35, 481-494

Perera A., Maia J.P.M.C., Jorge F., Harris D.J. 2013. Molecular screening of nematodes in lacertid lizards from the Iberian Peninsula and Balearic Islands using 18S rRNA sequences. Journal of Helminthology, 87, 189-194. DOI: 10.1017/S0022 149X12000181

Poulin R., George-Nascimento M. 2007. The scaling of total parasite biomass with host body mass. International Journal for Parasitology, 37, 359-364. DOI:10.1016/j.ijpara.2006.11.009

Prosser S.W.J., Velarde-Aguilar M.G., Léon-Règagnon V., Hebert P.D.N. 2013. Advancing nematode barcoding: A primer cocktail for the cytochrome c oxidase subunit I gene from vertebrate parasitic nematodes. Molecular Ecology Resources, 13, 1108-1115. DOI: 10.1111/1755-0998.12082

Sanmartin-Duran M.L., Quinteiro P., Ubeira F.M. 1989. Nematode parasites of commercially important fish in NW Spain. Diseases of Aquatic Organisms, 7, 75-77

Šantić M., Rađa B., Pallaoro A. 2012. Feeding habits of small-spotted catshark (Scyliorhinus canicula Linnaeus, 1758) from the eastern central Adriatic Sea. Marine Biology Research,11. DOI: $10.1080 / 17451000.2012 .702912$

Sims D.W., Nash J.P., Morritt D. 2001. Movements and activity of male and female dogfish in a tidal sea lough: alternative behavioural strategies and apparent sexual segregation. Marine Biology, 139, 1165-1175. DOI: 10.1007/s002270100666

UNEP-MAP-RAC/SPA. 2013 Fisheries in the Gulf of Lions. 79 pp. In: Farrugio H. (Ed.). Tunis, RAC/SPA

Valls M., Quetglas A., Ordines F., Moranta J. 2011. Feeding ecology of demersal elasmobranchs from the shelf and slope off the Balearic Sea (western Mediterranean). Scientia Marina, 75, 633-639. DOI: 10.3989/scimar.2011.75n4633

Whiting M.F. 2002. Mecoptera is paraphyletic: multiple genes and phylogeny of Mecoptera and Siphonaptera. Zoologica Scripta, 31, 93-104. DOI: 10.1046/j.0300-3256.2001.00095.x

Yeld E.M. 2009. Parasite Assemblages of Three Endemic Catshark Species from the West and South Coasts of South Africa. PhD thesis. University of Cape Town, pp. 350

Zuur A.F., Ieno E.N., Walker N.J., Saveliev A.A., Smith G.M. 2009. Mixed Effects Models and Extensions in Ecology with R. Springer-Verlag, New York, pp. 574 